\title{
Correction to: Predicting the accuracy of genomic predictions
}

\author{
Jack C. M. Dekkers ${ }^{*} \mathbb{D}$, Hailin Su and Jian Cheng
}

\section{Correction to: Genet Sel Evol (2021) 53:55} https://doi.org/10.1186/s12711-021-00647-w

After publication of [1], several errors in references to equations were noted.

In the Methods section entitled " $M_{e}$ for the reference population", reference to Eqs. (6), (7), and (9) must be replaced by Eqs. (5), (6), and (8) in the sentence: "These two accuracies can then be combined to predict $r_{G_{r}}$, using either the Fisher approach (Eqs. (5) and (6)) or the Index approach (Eq. (8))."

In the subsequent paragraph, (3)(b), reference to Eq. (6) must be replaced by Eq. (4) in the sentence: "Using the Index approach, $r_{D_{r}}^{2}$ can be computed from the observed $r_{G_{r}}$ and $r_{A_{r}}$ using Eq. (9), which can then be used to compute $\theta_{D}$ for a given value of $q_{D}^{2}$ using Eq. (4)."

Also, in Appendix 2, the off-diagonals in the matrix must be multiplied by $r_{A} r_{D}$ in:

$$
\left[\begin{array}{l}
b_{A} \\
b_{D}
\end{array}\right]=\left[\begin{array}{cc}
r_{A}^{2} & r_{\widehat{g}_{A}, \widehat{g}_{D}} r_{A} r_{D} \\
r_{\widehat{g}_{A}, \widehat{g}_{D}} r_{A} r_{D} & r_{D}^{2}
\end{array}\right]^{-1}\left[\begin{array}{l}
r_{A}^{2} \\
r_{D}^{2}
\end{array}\right]
$$

which then results in:

$$
=\frac{1}{r_{A} r_{D}\left(1-r_{\widehat{g}_{A}, \widehat{g}_{D}}{ }^{2}\right)}\left[\begin{array}{l}
r_{A} r_{D}-r_{D}^{2} r_{\widehat{g}_{A}, \widehat{g}_{D}} \\
r_{A} r_{D}-r_{A}^{2} r_{\widehat{g}_{A}, \widehat{,}_{D}}
\end{array}\right]
$$

The original article can be found online at https://doi.org/10.1186/s12711021-00647-w.

*Correspondence: jdekkers@iastate.edu

Department of Animal Science, lowa State University, Ames, IA, USA
In the next line, the square is missing on the left-handside of: $r_{\widehat{g}_{A}, \widehat{g}_{D}}^{2}=r_{A}^{2} r_{D}^{2}$

In the last line, the subscript in $\operatorname{cov}\left(\widehat{g}_{D}, g_{D G}\right)$ should be G instead of DG, i.e.

$$
r_{G}^{2}=\left[\begin{array}{l}
b_{A} \\
b_{D}
\end{array}\right]^{\prime}\left[\begin{array}{l}
\operatorname{cov}\left(\widehat{g}_{A}, g_{G}\right) \\
\operatorname{cov}\left(\widehat{g}_{D}, g_{G}\right)
\end{array}\right]
$$

\section{Acknowledgements}

The authors thank Dr. Piter Bijma for pointing us to the error in Appendix 2.

Published online: 15 October 2021

\section{Reference}

1. Dekkers JCM, Su H, Cheng J. Predicting the accuracy of genomic predictions. Genet Sel Evol. 2021;53:55. https://doi.org/10.1186/ s12711-021-00647-W.

\section{Publisher's Note}

Springer Nature remains neutral with regard to jurisdictional claims in published maps and institutional affiliations.

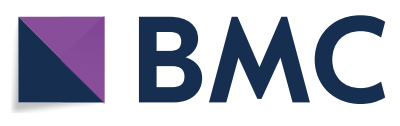

(c) The Author(s) 2021. Open Access This article is licensed under a Creative Commons Attribution 4.0 International License, which permits use, sharing, adaptation, distribution and reproduction in any medium or format, as long as you give appropriate credit to the original author(s) and the source, provide a link to the Creative Commons licence, and indicate if changes were made. The images or other third party material in this article are included in the article's Creative Commons licence, unless indicated otherwise in a credit line to the material. If material is not included in the article's Creative Commons licence and your intended use is not permitted by statutory regulation or exceeds the permitted use, you will need to obtain permission directly from the copyright holder. To view a copy of this licence, visit http://creativecommons.org/licenses/by/4.0/. The Creative Commons Public Domain Dedication waiver (http://creativeco mmons.org/publicdomain/zero/1.0/) applies to the data made available in this article, unless otherwise stated in a credit line to the data. 